Indexed by

\title{
Scopus
}

\section{MECHANICAL PROPERTIES CHARACTERIZATION OF RAT-TRAP BOND BRICK MASONRY}

\section{Samiullah}

Research Scholar, Department of Civil Engineering, University of Engineering and Technology, Peshawar

\section{Mohammad Ashraf}

Faculy Member, Department of Civil Engineering, University of Engineering and Technology, Peshawar

\section{Muhammad Fahim}

Faculy Member, Department of Civil Engineering, University of Engineering and Technology, Peshawar

\section{Muhammad Haris}

Research Scholar, Department of Civil Engineering, University of Engineering and Technology, Peshawar

\section{Sajjad Wali Khan}

Faculy Member, Department of Civil Engineering, University of Engineering and Technology, Peshawar

\section{Sajjad Wali Khan}

Faculy Member, Department of Civil Engineering, University of Engineering and Technology, Peshawar

Key words: rat-trap bond, RTB, cost-effectiveness, compressive strength, diagonal strength mechanical properties, stress-strain relationship

doi:10.5937/jaes0-33000

Cite article:

Samiullah., Ashraf M., Fahim M., Haris M., Wali Khan S., Wali Khan S. (2022) MECHANICAL PROPERTIES CHARACTERIZATION OF RAT-TRAP BOND BRICK MASONRY, Journal of Applied Engineering Science, 20(2), 365 - 371, DOI:10.5937/ jaes0-33000

Online aceess of full paper is available at: www.engineeringscience.rs/browse-issues 


\title{
MECHANICAL PROPERTIES CHARACTERIZATION OF RAT-TRAP BOND BRICK MASONRY
}

\author{
Samiullah', Mohammad Ashraf', Muhammad Fahim ${ }^{2 *}$, Muhammad Haris', Sajjad Wali Khan', Wajid Khan ${ }^{2}$ \\ ${ }^{1}$ Research Scholar, Department of Civil Engineering, University of Engineering and Technology, Peshawar \\ ${ }^{2}$ Faculy Member, Department of Civil Engineering, University of Engineering and Technology, Peshawar
}

Brick masonry is one of the most popular building technique for residential buildings, especially in the developing countries. The two most common types of bonds adopted in brick masonry are English and Flemish. However, rattrap bond is gaining popularity in South Asian countries like India, Pakistan, and Sri Lanka. It is a type of masonry bond in which shiners and rowlocks are laid on the edges such that the shiners have 1/3rd cavity between them resulting in cost reduction, dead load reduction, faster construction and thermal insulation, etc. This paper presents the results of an experimental investigation of rat-trap bond masonry for mechanical characterization. Four prism specimens were tested for compressive strength, four for diagonal strength, and twelve triplets were tested for shear strength. It was found that the mechanical properties of rat-trap masonry lie within the range of English bond masonry in Pakistan as determined by various researchers. In addition, the compressive strength and elastic modulus were found within the specified range of Building Code of Pakistan, while the shear modulus showed higher values.

Key words: rat-trap bond, RTB, cost-effectiveness, compressive strength, diagonal strength mechanical properties, stress-strain relationship

\section{INTRODUCTION}

Brick masonry is used worldwide in the construction industry. It has gone through a number of evolutions regarding cost-effectiveness and structural systems. The modern world, especially the developing countries are in search of energy efficient and cost-effective construction techniques. Rat-trap bond (RTB) masonry is one such technique which addresses both these demands. It is a type of masonry bond in which shiners and rowlocks are laid on edges such that the shiners have $1 / 3$ rd cavity between them as shown in Figure 1. This cavity results in cost reduction, dead load reduction, faster construction and thermal insulation (the cavity between the two wythes reduces the transfer of heat), etc. [1-2]. These properties made the RTB attractive for construction industry; however, its structural safety and feasibility need to be evaluated properly. RTB was used till the end of 19th century for the construction of two storey buildings in the United Kingdom and some other British colonies of North America and Southern Hemisphere [3]. However, the RTB lost its identity later on and get disappeared from the construction industry. During the 1970s, Lauri Baker re-introduced RTB in India along with other cost effective techniques for cost-effective constructions in India. This was a turning point for RTB as researchers initiated various studies to investigate the mechanical properties and structural performance of RTB, while the construction industries, especially in the developing countries adopted RTB once again. Different countries like Nepal, Sri Lanka, and India has developed guidelines for its use. India has also included guidelines of RTB in the National Building Code of India in 2016 [4].
Pakistan has also adopted the RTB for the construction of buildings all over the country. It was used to construct hundreds of Government schools by IMC-Worldwide under the project titled "Hamqadam" in various districts of Pakistan [5].

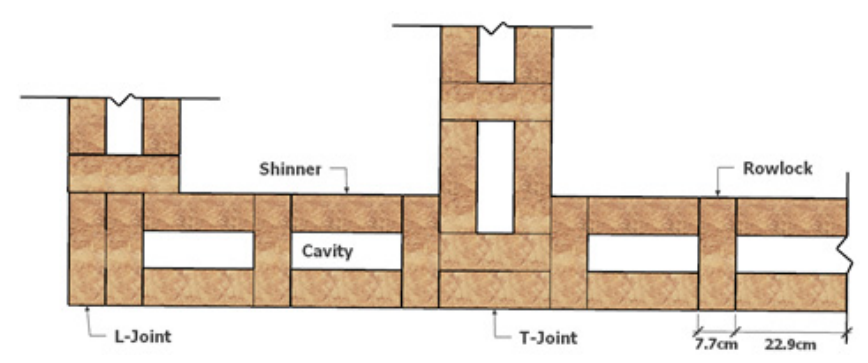

Figure 1: Typical layout of RTB showing top view with " $L$ " and "T" joints

The literature survey reveals that the compressive strength of RTB ranges from 1.1-3.2 MPa [6-8]. This difference is due to the fact that the area effective in taking the stresses is calculated differently by various researchers. The thermal insulation of RTB is reported to be varying from $25-30 \%$ [9]. The cost effectiveness of RTB was reported to be varying from $20-30 \%$ of the total cost of conventional masonry $[2,8,10]$. Researchers have also studied load-deformation curves and reported that the behavior of RTB is somehow similar to conventional masonry up to the yield limit with a $30 \%$ reduction in yield strength [11]. The comparison of RTB and English bond shows that RTB has reduced compressive and diagonal strengths $[8,11]$. The successful adoption of a new construction technique requires a comprehensive 
set of experimental and field data, easily available numerical or empirical models for design and assessment, and the availability of relevant standards and specifications. Keeping in view the desirable properties of RTB in terms of energy savings and cost effectiveness, a comprehensive experimental program is being carried out at the Civil Engineering Department of University of Engineering and Technology, Peshawar, Pakistan. This paper presents the mechanical properties of RTB including compressive strength, diagonal shear strength, cohesion, coefficient of friction, stress-strain relationship as well as detailed discussion on the failure mode of RTB under compression and diagonal tension. The results are also compared with specifications of Building Code of Pakistan (BCP) as well as with various studies conducted in the past for English bond masonry in Northern Pakistan.

\section{EXPERIMENTAL PROGRAM}

The experimental program was devised such that the masonry constituent materials were tested in the first phase, while the masonry prisms were tested in the second phase. The details of various tests conducted are given in Table 1. In order to keep the workmanship constant, all the specimens were constructed using the same mason. The specimens were moist cured for at least 28 days. The conventional wire mechanism used for measuring deformation may over or under calculate the deformation because of the tension in the wire and the knot provided in the wire. Therefore, the deformation was measured using an alternative mechanism, in which stiff aluminum strips were used instead of wire for measuring the deformation as shown in Figure 2.

Table 1: Details of various tests conducted

\begin{tabular}{|c|c|c|}
\hline Test conducted & $\begin{array}{c}\text { Standard } \\
\text { followed }\end{array}$ & $\begin{array}{c}\text { No. of } \\
\text { specimens }\end{array}$ \\
\hline $\begin{array}{c}\text { Initial rate of } \\
\text { absorption of brick }\end{array}$ & ASTM $^{*}$ C 67 & 5 \\
\hline $\begin{array}{c}\text { Compressive strength } \\
\text { of brick }\end{array}$ & ASTM C 67 & 5 \\
\hline $\begin{array}{c}\text { Modulus of rupture } \\
\text { (flexure strength of } \\
\text { brick) }\end{array}$ & ASTM C 67 & 5 \\
\hline $\begin{array}{c}\text { Compressive } \\
\text { strength of hydraulic } \\
\text { cement mortars }\end{array}$ & ASTM C 109 & 6 \\
\hline $\begin{array}{c}\text { Compressive strength } \\
\text { of masonry prisms }\end{array}$ & ASTM C 1314-14 & 4 \\
\hline $\begin{array}{c}\text { Diagonal tension } \\
\text { (shear) in masonry } \\
\text { assemblages }\end{array}$ & ASTM E 519-02 & 4 \\
\hline $\begin{array}{c}\text { Determination of } \\
\text { initial shear strength }\end{array}$ & EN 1052-3 & 12 \\
\hline
\end{tabular}

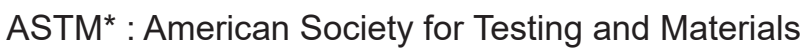
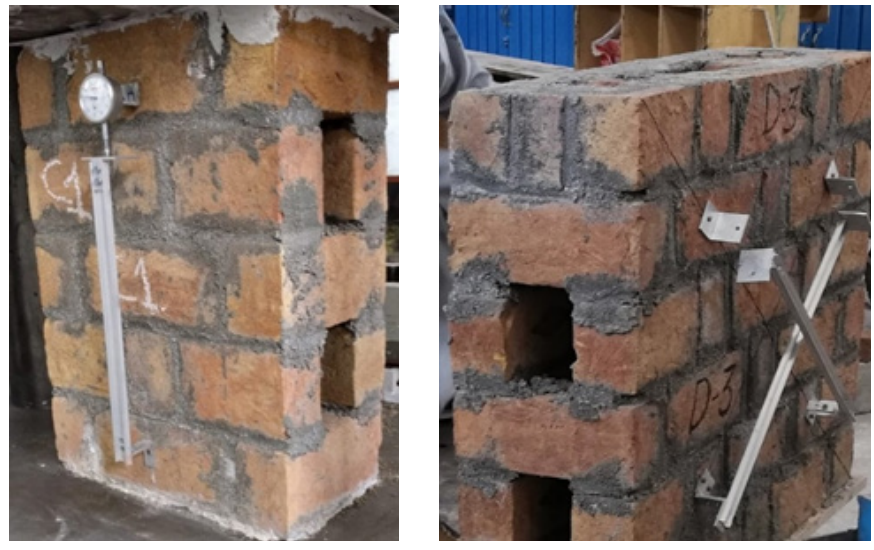

Figure 2: Deformation measuring mechanism

\section{Material Testing}

\section{Testing of Bricks}

Locally available bricks were selected for the construction of testing specimens. The bricks were tested for initial rate of absorption, compressive strength, and flexure strength. The tests were conducted in accordance with American Society for Testing and Materials (ASTM) C6719 [12]. The results of the brick units are presented in Table 2. According to Building Code of Pakistan (BCP: Section 9.9.2) [13], the minimum compressive strength of solid clay brick unit shall not be less than $8.25 \mathrm{MPa}$. The mean value of compressive strength was found to be $14.98 \mathrm{MPa}$, which is well above the minimum strength specified by BCP. However, there is no specified range for IRA and modulus of rupture of brick units in BCP.

\section{Testing of Mortar Cubes}

Locally available river sand was used for preparing mortar. The cement-sand ratio was kept at 1:6 with an adjustable amount of water to obtain a workable paste. Mortar cubes of size $5 \times 5 \times 5 \mathrm{~cm}$ from each batch were taken as representative samples of the mortar and were tested in the Universal Testing Machine (UTM) after a curing period of 28 days. The tests were conducted in accordance with ASTM C-109 [14] and the results are presented in Table 2. According to BCP (section 9.9.2) [13], the minimum compressive strength of mortar shall not be less than $5.5 \mathrm{MPa}$ and not greater than $75 \%$ of the masonry unit. The average compressive strength of mortar obtained was $6.60 \mathrm{MPa}$, which lies within the limits specified by BCP.

\section{Construction of Masonry Prisms}

\section{Specimens for Compressive Strength of RTB}

Four prism specimens were constructed in RTB having configuration as shown in Figure 3. The size of each specimen was $38.1 \times 22.86 \times 57.15 \mathrm{~cm}$. The specimens were tested in Universal Testing Machine (UTM) in accordance with ASTM C1314 [15], after a curing period of 28 days. In order to obtain a smooth surface for 
Table 2: Results of brick units and mortar used for construction of RTB specimens

\begin{tabular}{|c|c|c|c|c|c|}
\hline Material & No. of samples & Property & Test standard & Mean value & C.O.V* $\%$ \\
\hline Brick & 05 & $\begin{array}{c}\text { Initial rate of absorption } \\
\left(\mathrm{gm} / \mathrm{min} / 200 \mathrm{~cm}^{2}\right)\end{array}$ & ASTM C 67-19 & 48.33 & 17 \\
\hline Brick & 05 & $\begin{array}{c}\text { (Flexural test) Modulus } \\
\text { of rupture (MPa) }\end{array}$ & ASTM C 67-19 & 3.87 & 10 \\
\hline Brick & 05 & $\begin{array}{c}\text { Compressive strength } \\
(\mathrm{MPa}), \text { fb }\end{array}$ & ASTM C 67-19 & 14.98 & 7 \\
\hline Mortar & 06 & $\begin{array}{c}\text { Compressive strength } \\
(\mathrm{MPa}), \text { fm }\end{array}$ & ASTM C 109 & 6.60 & 13 \\
\hline
\end{tabular}

C.O.V*: Coefficient of Variance

uniform application of load, the specimens were caped using gypsum. The change in length due to compression was also measured using dial gauges in order to obtain stress-strain curve and to calculate the modulus of elasticity. The results for compression tests are summarized in Table 3.
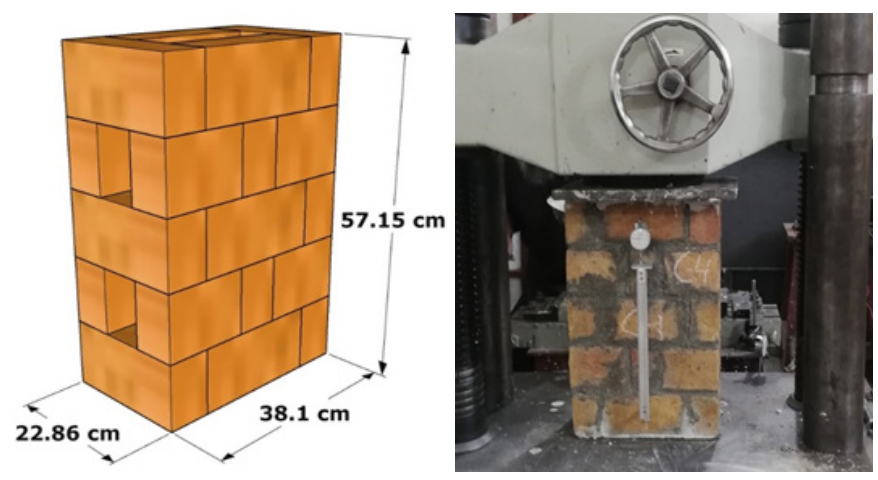

Figure 3: (a) Perspective view of RTB prism for compressive strength and (b) testing arrangements

\section{Specimens for Direct Shear/Triplet Test of RTB}

In order to find the direct shear strength parameters i.e. coefficient of friction and cohesion, triplet tests were conducted in accordance with EN 1052-3 [16] as ASTM has no standard defined for direct shear strength test. A typical test specimen for direct shear test is shown in Figure 4. Twelve samples were tested in four groups i.e. three samples each under a pre-compression of $0.0,0.2,0.6$, and 1.0 MPa stress.
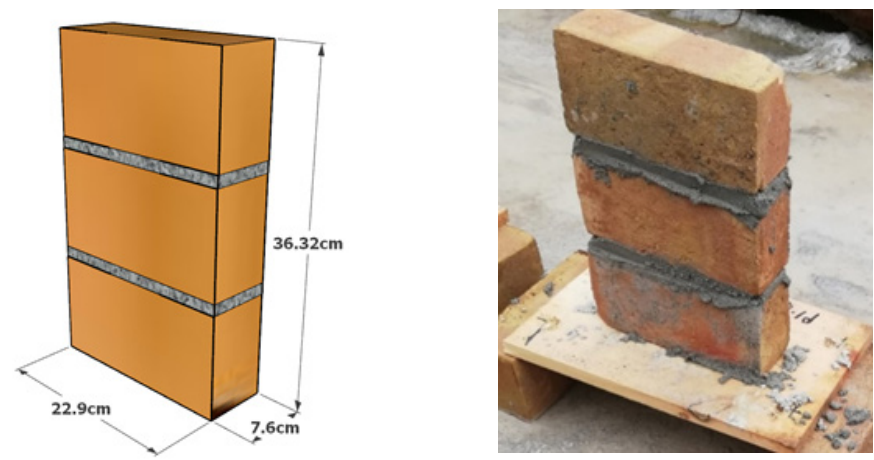

Figure 4: Typical specimen for triplet/direct shear test

\section{Specimens for Diagonal Strength of RTB}

Four specimens each having size $68.58 \times 22.86 \times 68.58$ inch were constructed in RTB. A typical test specimen and testing arrangements for the diagonal strength test are shown in Figure 5. The specimens were tested in accordance with ASTM E-519 standards [17]. The extension and shortening of the diagonals were measured using manual dial gauges. The results from the diagonal shear tests are summarized in Table 4.

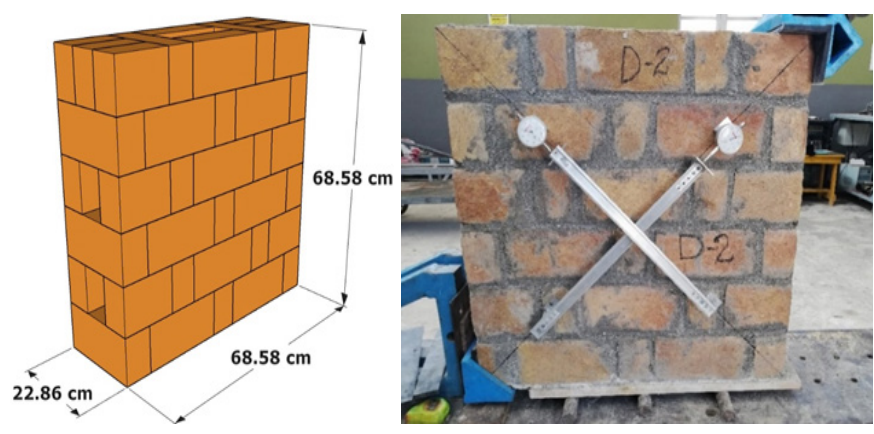

Figure 5: A typical RTB prism for diagonal strength test and testing arrangements

\section{Results and Discussion}

\section{Compressive Strength and Modulus of Elasticity}

The results of compressive strength tests for all four specimens are shown in Table 3. The compressive strength was calculated based on the net effective area. The cavity and the unsupported rowlock brick merely acts as a connection between the two wythes and hence do not contribute to the compression area. Therefore, the net effective area was taken as $2 / 3$ rd of the gross cross-sectional area of the wall. Based on the use of the net effective area and stronger brick units, the results obtained are significantly higher than those reported in the literature. The elastic modulus $(\mathrm{Em})$ was calculated from the plot of the stress-strain curve Figure 6 using the secant modulus between $1 / 20$ th and $1 / 3$ rd of the peak load as specified by ASTM E-447 [18]. The experimental value of Em was 562 times the compressive strength of masonry, which lies within the range specified by BCP 
[13], according to which the elastic modulus of masonry prism should not exceed 750 times the compressive strength of masonry.

Table 3: Compressive strength and modulus of elasticity of RTB masonry

\begin{tabular}{|c|c|c|c|}
\hline Prism & $\begin{array}{c}\text { Net effective } \\
\text { Area }\left(\mathrm{cm}^{2}\right)\end{array}$ & $\begin{array}{c}\text { Compressive } \\
\text { strength (MPa) }\end{array}$ & $\begin{array}{c}\text { Modulus } \\
\text { of elasticity } \\
(\mathrm{MPa})\end{array}$ \\
\hline C-1 & 603.31 & 4.76 & 1,984 \\
\hline C-2 & 603.96 & 3.94 & 2,630 \\
\hline C-3 & 603.96 & 6.10 & 4,068 \\
\hline C-4 & 600.68 & 4.26 & 2,029 \\
\hline Average & & 4.77 & 2677 \\
\hline C.O.V\% & & 20 & 36 \\
\hline
\end{tabular}

\section{Stress-Strain Curve}

The compression strain was calculated from the recorded deformation and was plotted against the corresponding stress to obtain the stress-strain curves of masonry prisms. A typical stress-strain curve obtained for RTB masonry is shown in Figure 6. The curve followed a linear trend up to approximately one-half of the peak stress. The strain increases significantly at a higher rate after the peak stress with a comparatively less decrease in stress showing a ductile nature.

\section{Failure Pattern under Compression}

A typical failure mode of RTB masonry prism in compression is shown in Figure 7. It was observed that the failure pattern was dominated by the failure of rowlock bricks. The rowlock is unsupported in the mid-span due to cavity, which makes it the weaker zone of RTB masonry. A similar failure pattern was also observed by Santhakumar and A. Sivakumar [7]. They used bricks of different strengths as rowlocks, and as expected, the specimens with stronger rowlock bricks showed higher compressive strength.

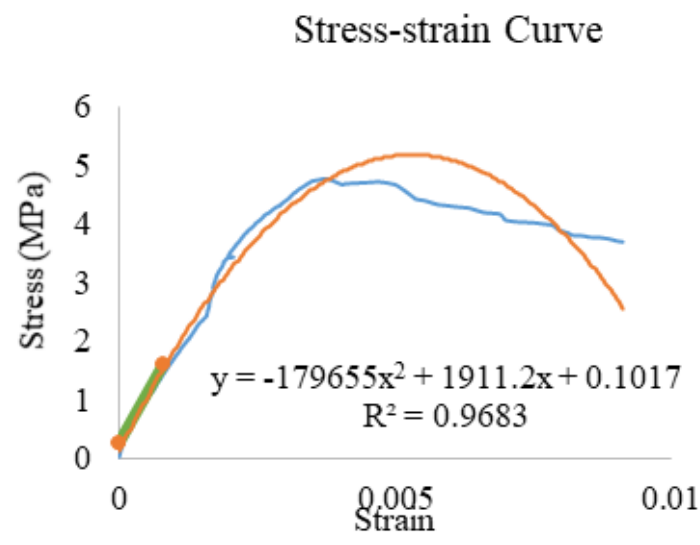

Figure 6: stress-strain curve of RTB
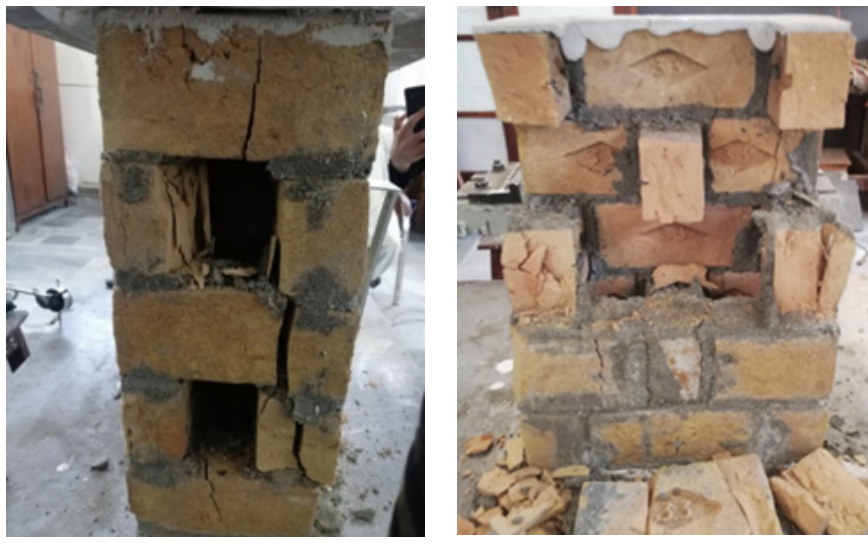

Figure 7: Failure mode RTB under compressive load

\section{Direct Shear Strength}

The shear and normal strength were calculated from the recorded data and were plotted against each other as shown in Figure 8 . The linear trend line equation was fitted which shows that the coefficient of friction $(\mu)$ and cohesion (C) of RTB are 0.45 and $0.1134 \mathrm{MPa}$ respectively. The failure pattern was dominated by sliding of mortar interface as shown in Figure 9. The values are quite smaller as compared to those usually found for conventional bonds because of the reduction in effective area due to the laying of bricks on the vertical face. The vertical face also has no frog, which also leads to reduction in the magnitude of the properties $\mu$ and $C$.

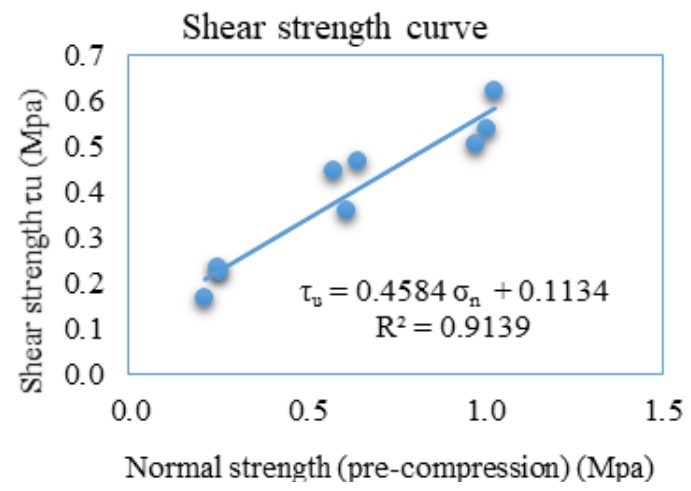

Figure 8: Shear strength vs normal strength of RTB

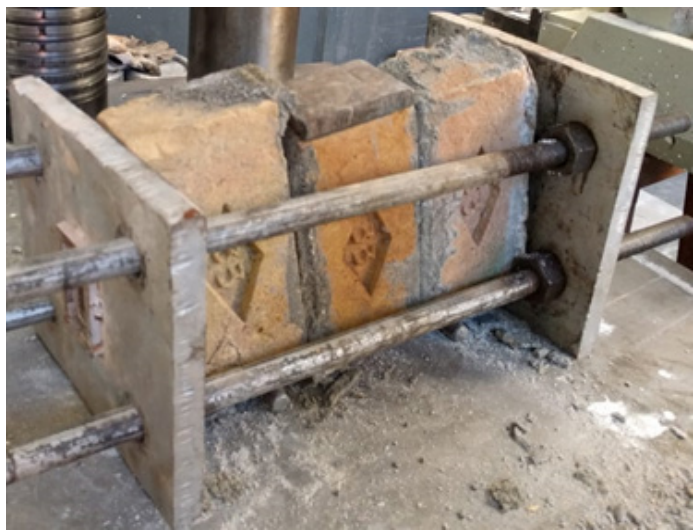

Figure 9: Typical failure pattern during triplet test 


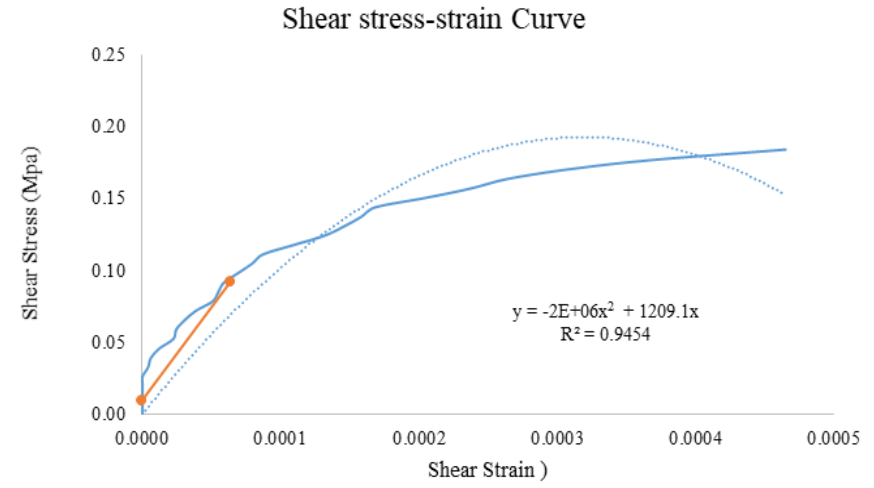

Figure 10: Shear stress strain curve of RTB

\section{Diagonal Tensile Strength}

The results of diagonal tensile strength are presented in Table 4 and a plot between diagonal stress and diagonal strain was obtained as shown in Figure 10. This plot was used to calculate the shear modulus of RTB. As ASTM does not specify any standard procedure for calculating shear modulus, therefore following the literature, it was calculated using the same secant modulus method as used for elastic modulus. The shear and tensile strength of RTB masonry were found to be $4 \%$ and $3 \%$ of the compressive strength of RTB masonry, respectively. Similarly, the shear modulus $(\mathrm{Gm})$ was found to be 0.76 times the elastic modulus $(\mathrm{Em})$, which is higher than $0.4 \mathrm{Em}$ as specified by BCP.

Table 4: Results of diagonal shear strength test

\begin{tabular}{|c|c|c|c|c|}
\hline $\begin{array}{c}\text { Prism } \\
\text { Label }\end{array}$ & $\begin{array}{c}\text { Area Net } \\
(\mathrm{cm} 2)\end{array}$ & $\begin{array}{c}\text { Shear } \\
\text { Strength } \\
(\mathrm{MPa})\end{array}$ & $\begin{array}{c}\text { Principal } \\
\text { Tensile } \\
\text { Strength } \\
(\mathrm{MPa})\end{array}$ & $\begin{array}{c}\text { Modulus } \\
\text { of Rigidity } \\
(\mathrm{G}) \mathrm{MPa}\end{array}$ \\
\hline D-1 & 1059 & 0.17 & 0.12 & 1989 \\
\hline D-2 & 1056 & 0.18 & 0.13 & 1310 \\
\hline D-3 & 1060 & 0.21 & 0.15 & 2982 \\
\hline D-4 & 1050 & 0.22 & 0.16 & 1820 \\
\hline & Average & 0.20 & 0.14 & 2025 \\
\hline & C.O.V $\%$ & 12 & 12.12 & 34.57 \\
\hline
\end{tabular}

\section{Failure Pattern}

The failure pattern of a typical diagonal shear prism can be seen in Figure 11. The crack pattern shows that pure diagonal shear failure mode was dominated. The crack propagated through mortar joints following the interface of rowlock and shiner. No brick failure was observed due to weak mortar and strong bricks.

\section{COMPARISON OF RTB MATERIAL PROPERTIES WITH ENGLISH BOND MASONRY}

Various parameters of RTB prisms are compared with the reported values of English bond prism in Northern Pakistan as shown in Table 5. The material properties
Table 5: Comparison of RTB masonry prism with English bond masonry

\begin{tabular}{|c|c|c|}
\hline Property & RTB & $\begin{array}{c}\text { English Bond } \\
\text { in Northern } \\
\text { Pakistan [19-24] }\end{array}$ \\
\hline $\begin{array}{c}\text { Compressive strength of } \\
\text { brick, (MPa) }\end{array}$ & 14.98 & $12.4-22.0$ \\
\hline $\begin{array}{c}\text { Compressive strength of } \\
\text { mortar, (MPa) }\end{array}$ & 6.60 & $4.9-13.21$ \\
\hline $\begin{array}{c}\text { Modulus of rupture of } \\
\text { brick, (MPa) }\end{array}$ & 3.87 & $2.7-6.3$ \\
\hline $\begin{array}{c}\text { Compressive strength of } \\
\text { prism,(MPa) }\end{array}$ & 4.76 & $3.0-5.8$ \\
\hline Cohesion, C & 0.45 & 0.59 \\
\hline $\begin{array}{c}\text { Coefficient of friction, } \mu \\
\text { (MPa) }\end{array}$ & 0.11 & $0.24-0.38$ \\
\hline $\begin{array}{c}\text { Elastic Modulus , Em } \\
\text { (MPa) }\end{array}$ & 2677 & $1227-1999$ \\
\hline Shear Modulus, Gm (MPa) & 2025 & $194-9969$ \\
\hline $\begin{array}{c}\text { Diagonal shear strength, } \\
\text { (MPa) }\end{array}$ & 0.20 & $0.09-0.35$ \\
\hline $\begin{array}{c}\text { Principal/Diagonal tensile } \\
\text { strength, (MPa) }\end{array}$ & 0.14 & $0.005-0.24$ \\
\hline
\end{tabular}

of RTB masonry lie within the range of results obtained for English bond masonry in Northern Pakistan except for cohesion, coefficient of friction, and elastic modulus. The cohesion and coefficient of friction of RTB are significantly smaller as compared to the English bond. This is because of the reduced effective area as well as lack of the frog in the vertical face, used in the construction of triplets. The elastic modulus (Em) of RTB is significantly higher than that of the English bond but lies within the range specified by $\mathrm{BCP}$, according to which, the maximum value of elastic modulus should be 750 times the compressive strength of prism. The increase in elastic modulus may be attributed to the alternate mechanism of measuring the deformation using aluminum strips. As far as shear modulus is concerned, it is 0.76 times Em which is greater than $0.4 \mathrm{Em}$ as specified by BCP. The variation in the reported values of shear modulus for English bond is too high and it is hard to achieve an acceptable range.

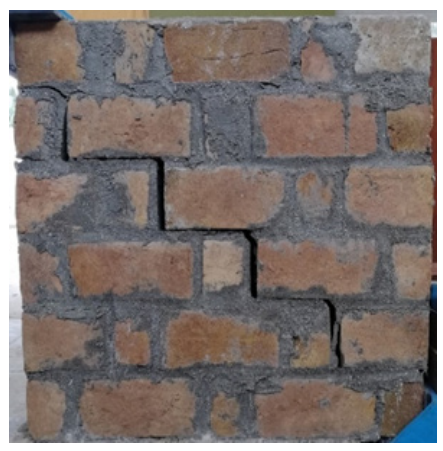

Figure 11: Typical failure mode of diagonal prism 


\section{CONCLUSIONS}

This study was carried out to study the properties of RTB masonry by testing prisms under compression, direct shear, and diagonal tension. The following can be concluded from the results obtained:

- The average compressive strength of RTB masonry was found to be $4.76 \mathrm{MPa}$, which lies within the range generally obtained for conventional masonry in Pakistan.

- The elastic modulus of RTB was determined to be $2677 \mathrm{MPa}$, which complies with the limits specified by $\mathrm{BCP}$.

- The weaker zone of RTB in compression is the rowlock brick.

- The coefficient of friction and cohesion were found to be comparatively less than that of the English bond masonry.

- The diagonal tensile strength and shear strength calculated were $0.14 \mathrm{MPa}$ and $0.20 \mathrm{MPa}$ respectively.

- The shear modulus of RTB was determined to be $2025 \mathrm{MPa}$, which is considerably higher than the range specified by $\mathrm{BCP}$.

- The material properties lie within the range generally obtained for English bond masonry, therefore it can be concluded that the bond can be successfully adopted as a load-bearing wall.

\section{ACKNOWLEDGMENT}

The authors are grateful to the Department of Civil Engineering, University of Engineering and Technology, Peshawar for allowing the use of their laboratory facilities. There was no funding received for conducting this study.

\section{REFERENCES}

1. Gilbile D, Dhopte P, Talegaonkar S, Khandait H, Harpal PD (2020). Study on Low Cost Housing with Roof Top Rainwater Harvesting. International Journal of Innovative Research in Technology, 6(11):526-30.

2. Chaudhary HR (2017). Cost Optimization Using Alternative Construction Techniques For Low Height Buildings. International Journal of Innovative Research and Advanced Studies. 4(7):159-63.

3. Dizhur D, Ingham J. (2015). Seismic Improvement of Loadbearing Unreinforced Masonry Cavity Walls. BRANZ Report ER3. DOI:10.13140/ RG.2.1.2335.0482

4. Bureau of Indian Standards. National building code of India 2016. Vol. 1. Bureau of Indian Standards. 78-82 p.

5. Humqadam SCRP, Humqadam - School Construction and Rehabilitation Program, from https://humqadam.pk/ accessed on 2019 Sep 11.
6. Medvedev P, Pugach E, Gaidukov P. (2019). Technological Application Features of Brickwork Bonding Types. IOP Conference Series: Materials Science and Engineering. 471(2):22-35.

7. Santhakumar AR,, A.Sivakumar SA. (2015). Validation of Rat-trap bond for cost effective housing. 9th Canadian Masonry Symposium.

8. Nauman Azhar M, Ali Qureshi L. (2020). Experimental study of structural behaviour of Chinese bond brick masonry: A new trend of durable \& economical construction in Pakistan. Journal of King Saud University - Engineering Sciences. DOI:10.1016/j. jksues.2020.09.013

9. Nadarajan M, Kirubakaran V. (2016). A comparison on simulation and validation of rural residential buildings using low cost technologies. International Journal of Applied Engineering Research. 11(1):484-91.

10. Khan A, Thaheem MJ. (2018). Comparison of performance of rat-trap brick bond with conventional brick bond. In: 1ST Int. conference on high performance energy efficient buildings and homes-Lahore. p. 255-62.

11. Jayasinghe C, Lakmali HDD, Rohitha MP. (2008). Comparative Performance of Masonry Bond Patterns. In: Annual transactions of the Institution of Engineers Sri Lanka. p. 38-46.

12. ASTM C67-07a, (2007). Standard test methods for sampling and testing brick and structural clay tile. ASTM West Conshohocken, PA, USA;

13. Building code of Pakistan, (2007). Seismic Provision, SP-2007. Ministry of housing and works, Government of Pakistan.

14. ASTM. C109/C109M-11, (2011). Standard test method for compressive strength of hydraulic cement mortars. ASTM West Conshohocken, PA, USA;

15. ASTM. C1314 - 09, (2015). Standard Test Method for Compressive Strength of Masonry Prisms. ASTM West Conshohocken, PA, USA;

16. European Committee for Standardization (CEN). EN 1052-3, (2007). Methods of test for masonry-Part 3: Determination of initial shear strength. European Committee for Standardization Brussels, Belgium.

17. ASTM. E519-02, (2005). Standard Test Method for Diagonal Tension (Shear) in Masonry Assemblages. ASTM West Conshohocken, PA, USA.

18. ASTM. E 447-97, (2017). Standard Test Methods for Compressive Strength of Laboratory Constructed Masonry Prisms. ASTM West Conshohocken, PA, USA.

19. Ashraf M. (2010). Development of Cost-effective and Efficient Retrofitting Technique for Masonry Buildings in Pakistan. PhD Dissertation. University of Engineering and Technology Peshawar, Pakistan. http://eprints.hec.gov.pk/9628/ 
20. Javed M. (2009). Seismic Risk Assessment of Unreinforced Brick Masonry Buildings System of Northern Pakistan. PhD Dissertation. University of Engineering \& Technology Peshawar, Pakistan.

21. Shahzada K, Khan AN, Elnashai AS, Ashraf M, Javed M, Naseer A, et al. (2012). Experimental seismic performance evaluation of unreinforced brick masonry buildings. Earthquake Spectra. 28(3):1269-90.

22. Ali Q, Naeem A. (2007). Seismic resistance evaluation of unreinforced masonry buildings. Journal of Earthquake Engineering. 11(2):133-46.
23. Naseer A. (2009). Performance Behavior of Confined Brick Masonry Buildings under Seismic Demand. PhD Dissertation. University of Engineering \& Technology Peshawar, Pakistan.

24. Sajid HU, Ashraf M, Ali Q, Sajid SH. (2018). Effects of vertical stresses and flanges on seismic behavior of unreinforced brick masonry. Engineering Structures; 155 394-409. DOl:10.1016/j.engstruct.2017.11.013 